\title{
Handexcuplat.
}

\section{Das in Bayern geltende}

$2 \mathfrak{a}$ d

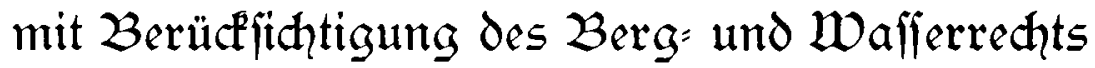
von

\section{Chriftian Meijner,}

Reditsanwalt in wär $\mathfrak{z}$ burg.

Bucite, volljtändig umgearbeitete und vermehrte Auflage.

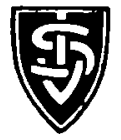

1910

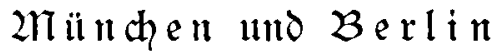

J. Sdqueiz̨er Verlag (Ürthur Sellier) 


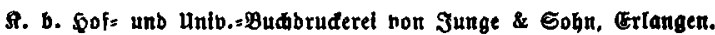

